\title{
A SIMPLE METHOD FOR THE DETERMINATION OF SERUM HAPTOGLOBINS
}

\author{
BY \\ J. A. OWEN,* F. C. BETTER, AND J. HOBAN \\ From the Clinical Biochemical Laboratory, St. Vincent's Hospital, Melbourne, Australia
}

(RECEIVED FOR PUBLICATION AUGUST 19, 1959)

Changes in the serum haptoglobin level have been reported in certain forms of anaemia (Allison and ap Rees, 1957; Allison, 1958; Nosslin and Nyman, 1958; Nyman, Gydell, and Nosslin, 1959), in hepatobiliary disease (Owen, Mackay, and Got, 1959) and in various inflammatory and chronic diseases (Jayle and Boussier, 1955; Allison and Blumberg, 1958). A simple colorimetric procedure for the determination of serum haptoglobins is presented. It is based on the peroxidase activity of haptoglobin-methaemoglobin complexes.

\section{Reagents and Apparatus}

Guiacol Reagent (Connell and Smithies, 1959).Guiacol (analytical grade), $3.72 \mathrm{~g}$., is dissolved in $700 \mathrm{ml}$. water to which is added $100 \mathrm{ml}$. of $1 \mathrm{M}$-acetic acid. The $p \mathrm{H}$ of the mixture is then adjusted to 4.0 by the addition of $1 \mathrm{M}$-sodium hydroxide, using a glass electrode $p \mathrm{H}$ meter. Finally the volume is made up to $1,000 \mathrm{ml}$.

Hydrogen Peroxide, 0.05 M.-This is prepared immediately before use by diluting a stock solution standardized by titration against standard potassium permanganate.

Methaemoglobin Solution.-To 8 vol. human erythrocytes, previously washed three times with saline, is added $3 \mathrm{vol}$. of water and 1 vol. of ether. The mixture is shaken and centrifuged, and the clear haemolysate pipetted off. The concentration of haemoglobin in the haemolysate is determined, using one of the standard methods for the determination of haemoglobin in blood and the solution diluted until the haemoglobin concentration is $1 \mathrm{~g} . / 100 \mathrm{ml}$. To $25 \mathrm{ml}$. of this solution is added $10 \mathrm{ml}$. of potassium ferricyanide $(100 \mathrm{mg}$. $/ 100 \mathrm{ml}$.) to convert the haemoglobin to methaemoglobin. After $10 \mathrm{~min}$. the volume is made up to $500 \mathrm{ml}$. The solution can be stored for several weeks at $0^{\circ} \mathrm{C}$.

Sodium Chloride, $0.15 \mathrm{M}$.

Procedure.-The test serum ( 1 vol.) is diluted with saline (4 vol.). To $1 \mathrm{ml}$. aliquots of diluted serum is added $1 \mathrm{ml}$. of methaemoglobin solution and $1 \mathrm{ml}$. of water respectively. Two test-tubes, each containing $5 \mathrm{ml}$. of guaicol reagent, are placed in a water-bath fitted with a lid and set at $25^{\circ} \mathrm{C}$. After $10 \mathrm{~min}$., $0.1 \mathrm{ml}$. of the mixture of diluted serum and methaemoglobin solution is added to the first tube and $0.1 \mathrm{ml}$. of the mixture of diluted serum and water, as a blank,

* In receipt of a grant from the National Health and Medical Research Council of Australia. to the second. Immediately thereafter $1.0 \mathrm{ml}$. of hydrogen peroxide, previously warmed to $25^{\circ} \mathrm{C}$., is added to each tube and the contents of the tubes quickly mixed. After eight minutes the tubes are removed from the bath and the optical densities of the solutions measured in a photoelectric colorimeter at a wavelength of $470 \mathrm{~m} \mu$ or using a blue filter. The instrument is set to zero with water and readings are made within four minutes. With multiple tests, timing is such that all tubes are treated similarly. The coloured material formed during the reaction (tetraguiacol) fades slowly if exposed to bright daylight. The lid of the water-bath should therefore be closed during the development of the colour and tubes should be kept in the dark until readings are made.

The concentration of haptoglobin is obtained from a calibration curve and is expressed in terms of bound methaemoglobin. If readings are too low or too near the maximum (Fig. 1), the test should be repeated using less diluted or more diluted serum. In this case, values from the calibration curve must be divided or multiplied accordingly.

The calibration curve is constructed as follows:

Portions $(1.0 \mathrm{ml}$.) of methaemoglobin solution are placed in each of 11 tubes. To these are added respectively increasing amounts of $(0.0,0.1,0.2,0.3$, . . $1.0 \mathrm{ml}$.) pooled normal serum free from haemolysis. Saline is then added, where necessary, so that the total volume in each tube is $2.0 \mathrm{ml}$. Each sample and a blank prepared with $0.1 \mathrm{ml} . \mathrm{NaCl}$ and $5 \mathrm{ml}$. guiacol is then submitted to the procedure described above. The photometer is set to zero with the blank. The readings are plotted against the amount of serum in each reaction tube (Fig. 1). The point of inflexion in the curve obtained indicates the amount of undiluted pooled serum which just binds all the methaemoglobin present since the addition of more serum does not significantly influence the readings (see Connell and Smithies, 1959). Thus, the reading at 


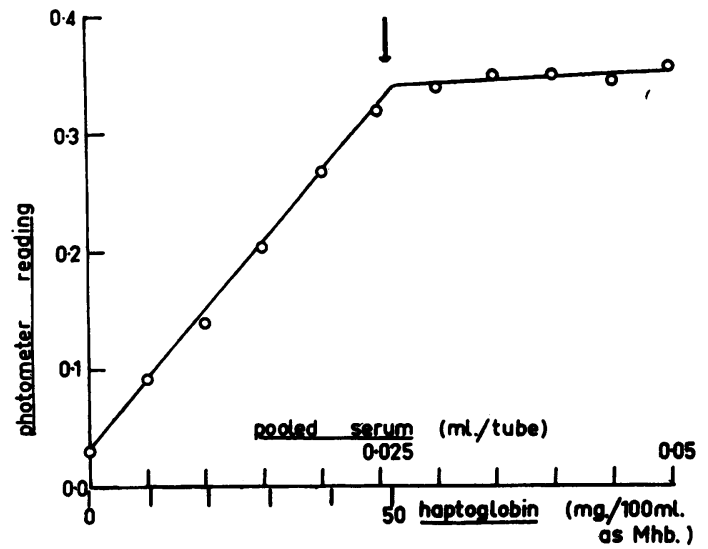

FIG. 1.-Calibration curve. Readings were obtained with a "unicam" SP1400 spectrophotometer at a wavelength of $470 \mathrm{~m} \mu$ using $10 \mathrm{~mm}$. diameter cuvettes. The arrow indicates the point of inflexion. The haptoglobin concentrations (lower scale on abscissa) are those of undiluted serum. With test sera, which are diluted, the values should be multiplied by the dilution factor. Normally this is 5 (see text).

this point corresponds to a methaemoglobin-binding capacity of $50 \mathrm{mg} . / 100 \mathrm{ml}$. Test sera, however, are normally diluted 1 in 5 so that, with these, the reading corresponds to a haptoglobin content of $250 \mathrm{mg}$./ $100 \mathrm{ml}$. (as methaemoglobin). The sloping part of the curve relates lower readings to the corresponding haptoglobin contents (Fig. 1).

\section{Discussion}

Polonovski and Jayle (1940) demonstrated that under certain conditions the peroxidase activity of the haemoglobin-haptoglobin complex is much greater than that of free haemoglobin. A similar phenomenon occurs with methaemoglobin (Connell and Smithies, 1959) and this forms the basis of the present method. By subtracting the reading for the serum blank from the test reading allowance is made for the reagent blank, for nonenzymatic oxidation of guiacol, and for the peroxidase activity of the serum itself, which in some cases is appreciable. This is presumably due to the presence of verdo-peroxidase from leucocytes (Agner, 1941). Methaemalbumin, if present, will also contribute to the serum blank. Under the conditions chosen, free methaemoglobin has a peroxidase activity about $10 \%$ of that of the methaemoglobin-haptoglobin complex (Fig. 1). However, allowance is made for the activity of any uncombined methaemoglobin in the construction of the calibration curve.

The sensitivity of the guiacol reagent slowly increases on standing, and a calibration curve should be made each week.
Sera should be free from haemolysis and should 을 not be diluted if the haptoglobin content is below $\overrightarrow{\vec{F}}$ $40 \mathrm{mg} . / 100 \mathrm{ml}$.

Calibration of the method in terms of methae- $\frac{C}{0}$ moglobin means that results obtained by different $\overline{\bar{c}}$. laboratories should be comparable since it is $\widehat{\Phi}$ generally possible to measure haemoglobin, from which the methaemoglobin is obtained, with ${ }^{\text {क }}$ reasonable precision. Eventually it should be $\vec{O}$ possible to standardize calibration curves using $\vec{\overrightarrow{ }}$ pure haptoglobin solution. The quantities ${ }_{\sigma}$ employed in constructing the calibration curve $\overrightarrow{0}$ have been calculated on the basis of a mean? normal serum haptoglobin concentration of $\vec{\omega}$ around $100 \mathrm{mg} . / 100 \mathrm{ml}$. (Jayle and Boussier, $\stackrel{N}{\sim}$ 1955 ; Laurell and Nyman, 1957 ; Nyman, 1958 ; $\overrightarrow{\mathrm{W}}$ Owen et al., 1959). Thus, approximately $0.025 \mathrm{ml}$. ᄋ of pooled normal serum should be equivalent to $0.05 \mathrm{ml}$. of the methaemoglobin solution $(50 \mathrm{mg} . / \bar{z}$ $100 \mathrm{ml}$.). We have found that the intrinsic peroxidase activity of pooled normal serum is $\frac{\rho}{\supset}$ sufficiently low to be neglected, especially if the $\vec{\bullet}$ sample has been stored frozen solid for some 8 days.

The method described here for the estimation 0 of serum haptoglobins gives more precise values than the simple electrophoretic methods used by Laurell and Nyman (1957) and by Owen et al. $\stackrel{\circ}{\varnothing}$ (1959) and is quicker than the electrophoretic $\varrho$ method described by Lathem and Worley (1959). $\overrightarrow{\vec{O}}$ The procedure described by Jayle (1951) gives 3 precise values but involves a titration carried out with very careful timing and utilizes a reagent (ethyl hydroperoxide) which is potentially 용 explosive (Baeyer and Villiger, 1901 ; Tobolsky $;$ and Mesrobian, 1954). The method devised by Connell and Smithies (1959) is likewise precise, but involves, for each sample, the taking of several readings at short intervals and requires a 0 spectrophotometer fitted with a thermostatically controlled chamber.

\section{REFERENCES}

Agner, K. (1941). Acta physiol. scand., 2, Suppl. 8.

Allison, A. C. (1958). Proc, roy. Soc. Med., 51, 641.

and Blumberg, B. S. (1958). Arth. Rheum., 1, 239. and ap Rees, W. (1957). Brit. med. J., 2, 1137 .

$\longrightarrow$ and ap Rees, W. (1957). Brit. med. J., 2, 1137.

Baeyer, A., and Villiger, V. (1901). Ber.dtsch. chem. Ges., 34, 738

Connell, G. E., and Smithies, O. (1959). Biochem. J., 72, 115

Jayle, M. F. (1951). Bull. Soc. Chim. biol. (Paris), 33, 876.

- and Boussier, G. (1955). Expos. ann. Biochim. méd., 17, 157. hem, W., and Worley, W. E. (1959). J. clin. Invest., 38, 474. \& Cited by Nosslin and Nyman (1958)

Laurell, C. B., and Nyman, M. (1957). Blood, 12, 493.

Nosslin, B. F., and Nyman, M. (1958). Lancet, 1, 1000.

Nosslin, B. F., and Nyman, M. (1958). Lancet,

Nyman, M. (1958). Clin. chim. Acta, 3, 111.

Gydell, K., and Nosslin, B. F. (1959). Ibid., 4, 82.

Owen, J. A., Mackay, I. R., and Got, C. (1959). Brit. med.J., 1, 1454.

Polonovski, M., and Jayle, M. F. (1940). C.R. Acad. Sci. (Paris), (D) 211, 517.

Tobolsky, A. V., and Mesrobian, R. B. (1954). Organic Peroxides : $\sigma$ Their Chemistry, Decomposition and Role in Polymerization. Interscience, New York. 